\title{
Light triggering of 5-aminolevulinic acid from fused coumarin ester cages
}

Ana M. S. Soares, ${ }^{a}$ Graham Hungerford, ${ }^{b}$ M. Sameiro T. Gonçalves ${ }^{a}$ and Susana P. G. Costa ${ }^{a, *}$

${ }^{a}$ Centro de Química, Universidade do Minho, Campus de Gualtar, 4710-057 Braga, Portugal

${ }^{b}$ HORIBA Jobin Yvon IBH Ltd, 133 Finnieston Street, Glasgow G3 8HB, UK

\section{Abstract}

The evaluation of the photorelease of 5-aminolevulinic acid (5-ALA), a small molecule which has considerable interest in the areas of medicine as a photosensitizer prodrug in PDT and cosmetic treatments, and in agriculture as herbicide/insecticide, was carried out by using a series of fused coumarin derivatives with different substituents and ring fusions in the preparation of 5 ALA photosensitive ester cages, in order to tune the photophysical and photolytic properties of the resulting conjugates. This study was intended to assess the viability of photorelease of 5-ALA from lipophilic conjugates since it has hydrophilic character, does not penetrate efficiently through the skin or cell membranes and proper derivatisation can enhance its lipophilicity and its application scope in biological environment. Photolysis studies were performed on the ester cages by irradiation in a photochemical reactor at 254, 300, 350 and $419 \mathrm{~nm}$, using methanol/HEPES buffer 80:20 solutions as solvent. The data obtained confirmed the suitability of the tested photosensitive moieties for the release of 5-aminolevulinic acid at the various wavelengths of irradiation. As well as the photolysis, the photophysics of the compounds were characterised by both steady state and time-resolved methods which uncovered the presence of different fluorescing species. Additionally, an on-off experiment was carried out by using two excitation sources (cleave and probe) to enable fluorescence to follow the kinetics of the process and to ascertain optical control over the bond scission.

\section{Introduction}

5-Aminolevulinic acid (5-ALA) is a key precursor in the biosynthesis of porphyrins such as chlorophyll and heme. It is frequently used with PDT because it can be interconverted to a potent photosensitizer, protoporphyrin IX (PpIX), via the heme biosynthetic pathway in mitochondria. 5-Aminolevulinic acid-based photodynamic therapy (ALAPDT) is gaining increasing acceptance in medicine as an effective technique for the 
treatment of a variety of neoplastic lesions and premalignant disorders. ${ }^{1}$ The first topical application of 5-ALA in the treatment of basal cell carcinoma was reported in 1990 and, since then, the clinical use of ALA-PDT has steadily grown and the methyl ester of 5-ALA has been approved for the treatment of basal cell carcinoma. ${ }^{2-4}$ Other applications of ALA-PDT include treatment of actinic keratosis, squamous cell carcinoma, Bowen's disease, acne, onychomycosis, verrucae and photorejuvenation, ${ }^{5-11}$ and it can also be used as a diagnostic tool for the visualization of precancerous changes in the mucosae by fluorescence spectroscopy. ${ }^{12,13}$

The main disadvantage of 5-ALA is that is poorly absorbed by cells due to its high hydrophilicity, by virtue of its zwitterion nature at physiological $\mathrm{pH}$, resulting in low bioavailability. However, this solubility enables fast clearance of 5-ALA from the body. In order to overcome the solubility issues, numerous efforts have been made to design 5-ALA prodrugs with a more favourable solubility profile such as esters, ${ }^{14-18}$ and peptide derivatives. ${ }^{19,20}$ The most successful 5-ALA derivatives are its methyl ester (methyl aminolevulinate, MAL) and hexyl ester (hexyl aminolevulinate, HAL). Elongation of a carbon chain attached to 5-ALA results in increased lipophilicity and in consequence higher membrane and skin permeability. The advantage of 5-ALA derivatives over 5-ALA can be mainly ascribed to: (i) the rate at which these compounds reach the target site, (ii) the rate at which they reach the intracellular space and (iii) the rate of their enzymatic conversion into photoactive compounds. ${ }^{21}$ For MAL, it has been reported that it also offers better tumour selectivity and less pain during PDT with less patient discomfort compared to ALA. ${ }^{22}$

Also, the herbicidal properties of 5-ALA are well documented. It belongs to the group of photodynamic herbicides/insecticides and its mechanism of action depends on its conversion to tetrapyrroles within plants/insects after application in the dark. This provides plant growth regulating properties at low concentrations and may enhance agricultural productivity by enhancing photosynthesis, suppressing respiration and stimulating carbon dioxide uptake. ${ }^{23-25}$

In prodrug design, it is of the utmost importance to control the scission of chemical bonds between the active drug and the promoiety that masks the activity, in order to regulate in time and space the availability of molecules with biological function, in the most biocompatible manner possible. Among the various triggering stimuli that can be used, i.e. enzymes, reducing or oxidising agents, temperature or $\mathrm{pH}$, the use of light represents a fast-developing methodology for application in controlled drug delivery. ${ }^{26-}$ 28 Photochemical cleavage is a very mild method that allows the cleavage of specific bonds within a structure with the consequent removal of protecting groups/promoieties and the on demand/on site release of an active molecule. Thus, photoactivable prodrugs incorporate a photosensitive promoiety (usually of heterocyclic nature) linked covalently to the active drug molecule.

Attempts to improve and tune the photosensitivity of the abovementioned heterocyclic promoieties to be adequate for biological applications have been achieved through 
synthetic tailoring in terms of substituents present in the structure and/or structural adjustments such as ring fusion and expansion of the aromatic system.

In the last few years, our research interests involve the release of bioorganic molecules from conjugates/cages possessing heterocyclic moieties specifically designed for using light as the triggering stimulus, to act as photoremovable protecting groups and phototriggers. Benzocoumarins and oxazole fused coumarins are examples of oxygen heterocycles used previously in the caging of amino acids, neurotransmitters, and also butyric acid. ${ }^{29-38}$

Considering the photolytic behaviour of such moieties and the consequent improvement as photolabile groups, the present work aims to evaluate their behaviour in the photorelease of 5-aminolevulinic acid, in an attempt to enhance its lipophilicity and its application scope assisted by light in biological environment.

\section{Results and discussion}

\section{Synthesis of 5-aminolevulinic acid conjugates 3a-e}

The photosensitive fused coumarins 1a-e were prepared as previously reported by us in good to excellent yields, through Pechmann condensation and intramolecular cyclisation reactions. ${ }^{29,36-38}$ 5-(N-tert-Butoxycarbonyl)aminolevulinic acid $\mathbf{2}$ was prepared from 5-aminolevulinic acid (5-ALA) by a standard amino group protection procedure with tert-butylpyrocarbonate. ${ }^{17}$

The chloromethyl precursors 1a-e were reacted with N-Boc-5-ALA 2 in the presence of potassium fluoride in $\mathrm{DMF}^{39}$ to afford the corresponding ester conjugates $3 a-e$ in fair to moderate yields (Scheme 1). As a representative example, conjugate $\mathbf{3 c}$ was subjected to acidic treatment with TFA in dichloromethane to remove the $\mathrm{N}$-protecting group yielding the corresponding conjugate $\mathbf{4 c}$ with the free amino group (Scheme 2 ).

Compounds $3 a-e$ and $\mathbf{4 c}$ were fully characterised by high resolution mass spectrometry, IR, ${ }^{1} \mathrm{H}$ and ${ }^{13} \mathrm{C}$ NMR spectroscopy. The IR spectra of compounds $\mathbf{3 a - e}$ and $\mathbf{4 c}$ displayed stretching vibration bands of the ester carbonyl group from 1699 to $1735 \mathrm{~cm}^{-1}$. ${ }^{1} \mathrm{H} \mathrm{NMR}$ spectra showed signals of 5-aminolevulinic acid at $\delta 2.78-2.89 \mathrm{ppm}$ for $\alpha$ - and $\beta-\mathrm{CH}_{2}$ and $\delta$ 3.98-4.09 ppm for $\delta-\mathrm{CH}_{2}$. The heterocycle methylene group, adjacent to the ester link, was visible for all compounds at $\delta 5.23-5.49 \mathrm{ppm}$. The newly formed ester linkages were confirmed by ${ }^{13} \mathrm{C}$ NMR spectra signals of the carbonyl group, at about $\delta 171.47-171.80$ ppm. 
<smiles>COc1cc2c(CCl)cc(=O)oc2c2ccccc12</smiles>

$1 a$<smiles>Nc1cc2c(CCl)cc(=O)oc2c2ccccc12</smiles>

$1 b$<smiles>COc1cc2c(COC(=O)CCC(=O)CNC(=O)OC(C)(C)C)cc(=O)oc2c2ccccc12</smiles>

3a $(20 \%)$<smiles>CC(C)(C)OC(=O)NCC(=O)CCC(=O)OCc1cc(=O)oc2c1cc(N)c1ccccc12</smiles>

3b $(42 \%)$<smiles>CCCCC(C)(C)OC(=O)NCC(=O)CCC(=O)CC(=O)OCc1cc(=O)oc2c(N)cccc12</smiles><smiles>O=c1cc(CCl)c2cc3nc(-c4ccccc4)oc3cc2o1</smiles>

1d

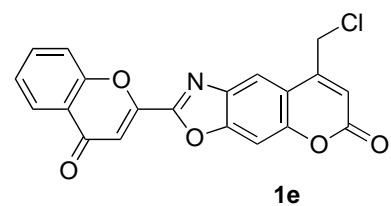<smiles>CC(C)(C)OC(=O)NCC(=O)CCC(=O)OCc1cc(=O)oc2cc3oc(-c4ccccc4)nc3cc12</smiles>

3d $(62 \%)$<smiles>CC(C)(C)OC(=O)NCC(=O)CCC(=O)OCc1cc(=O)oc2cc3oc(-c4cc(=O)c5ccccc5o4)nc3cc12</smiles>

3e $(56 \%)$

$\mathrm{h}$ $\mathrm{MeOH} / \mathrm{HEPES}$ $(80: 20)$

$2+$ photo by-products

Scheme 1. Synthesis of ester cages of 5-aminolevulinic acid 3a-e and photorelease of the $N$-protected carboxylic acid 2.

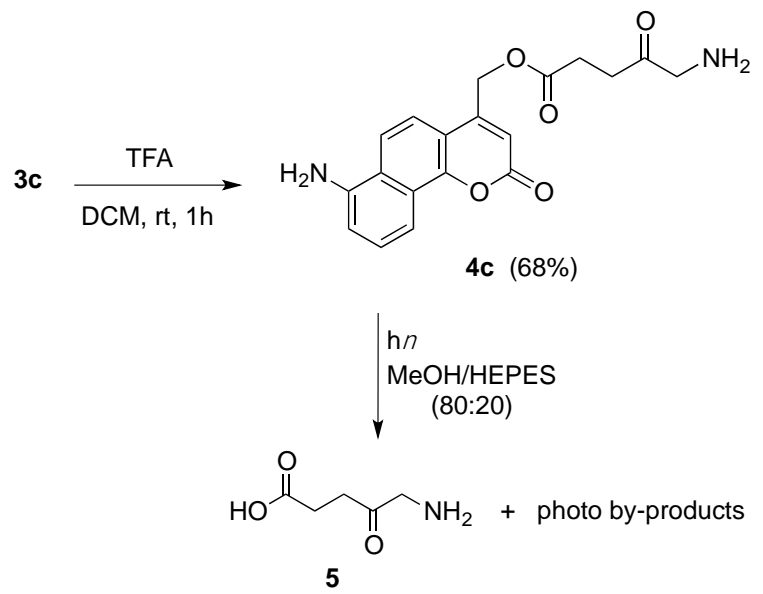

Scheme 2. Synthesis and photolysis of deprotected 5-ALA conjugate $\mathbf{4 c .}$ 
Evaluation of the photophysical properties of 5-aminolevulinic acid conjugates 3a-e and 4c

Fundamental UV/visible absorption and emission characterisation was performed for conjugates 3a-e and $\mathbf{4 c}$ considering that their photolysis would be monitored by HPLC with UV detection. The absorption and emission spectra of degassed $10^{-5} \mathrm{M}$ solutions in methanol/HEPES buffer (80:20) solutions of ester conjugates 3a-e and 4c were measured and the absorption and emission maxima, molar absorption coefficients and relative fluorescence quantum yields are reported in Table 1 . Relative fluorescence quantum yields were calculated using 9,10-diphenylanthracene in ethanol $\left(\Phi_{\mathrm{F}} 0.95\right)^{40}$ as a standard. For the $\Phi_{\mathrm{F}}$ determination, the fluorescence standard was excited at the maximum absorption wavelength found for each compound. In all fluorimetric measurements the absorbance of the solution did not exceed 0.1. For easier comparison, the data already published by us for precursors 1a-e was also included in Table 1.

From the data in Table 1 it was confirmed that the absorption and emission of the conjugates were directly related with the nature of the heterocyclic tag. As for the influence of the tag structure, by comparison of conjugates 3a-c with a benzocoumarin with the same ring fusion but different substituents at different positions (methoxy or amino groups), it could be seen that the methoxy derivative 3a exhibited longer wavelength of absorption (> $80 \mathrm{~nm}$ ) than that of amino derivatives $\mathbf{3 b}$-c.

Table 1. UV/Vis absorption and emission data for precursors 1a-e and conjugates 3a-e and $4 \mathbf{c}$, in methanol/HEPES buffer (80:20) solutions.

\begin{tabular}{llllll}
\hline & \multicolumn{3}{l}{ Absorption } & \multicolumn{3}{l}{ Emission } \\
\cline { 2 - 6 } Cpd. & $\begin{array}{l}\lambda_{\max } \\
\text { (nm) }\end{array}$ & $\log \varepsilon$ & $\begin{array}{l}\lambda_{\mathrm{em}} \\
(\mathrm{nm})\end{array}$ & $\begin{array}{l}\text { Stokes' shift } \\
(\mathrm{nm})\end{array}$ & $\Phi_{\mathrm{F}}$ \\
\hline $\mathbf{1 a}^{\mathbf{2 9}}$ & 383 & 3.70 & 471 & 88 & 0.01 \\
$\mathbf{1 b}^{36}$ & 291 & 5.32 & 302 & 11 & 0.02 \\
$\mathbf{1 c}^{37}$ & 291 & 3.92 & 318 & 27 & 0.08 \\
$\mathbf{1 d}^{38}$ & 341 & 3.98 & 397 & 56 & 0.06 \\
$\mathbf{1 e}^{38}$ & 306 & 3.85 & 444 & 138 & 0.04 \\
$\mathbf{3 a}$ & 376 & 5.81 & 479 & 103 & 0.28 \\
$\mathbf{3 b}$ & 291 & 3.66 & 320 & 29 & 0.23 \\
$\mathbf{3 c}$ & 291 & 3.71 & 340 & 49 & 0.32 \\
$\mathbf{3 d}$ & 340 & 3.89 & 417 & 77 & 0.06 \\
$\mathbf{3 e}$ & 347 & 3.86 & 453 & 106 & 0.39 \\
$\mathbf{4 c}$ & 291 & 3.70 & 339 & 48 & 0.12 \\
\hline
\end{tabular}


The fused coumarin oxazole conjugates $\mathbf{3 d , e}$ also showed a bathochromic shift compared to the latter but not as pronounced $(\approx 50 \mathrm{~nm})$. The same trend was seen in the fluorescence wavelength maxima. Considering conjugates $\mathbf{3 b}$ and $\mathbf{3} \mathbf{c}$ which differ in the relative position of the electron donor amino group, the $\lambda_{\mathrm{em}}$ was longer for substitution at position 7 (compound 3c), with a $20 \mathrm{~nm}$ bathochromic shift when compared with substitution at position 6 (compounds $\mathbf{3 b}$ ).

Overall, the emission spectra appeared structureless, which may be indicative of an emission that has a charge transfer nature. The fact that the fluorescence originates from the tag is further reinforced by the measurement of the excitation - emission matrix (EEM), which produces a contour plot of fluorescence intensity in relation to different excitation and emission wavelengths (Figure 1). The EEMs show that even excitation towards shorter wavelengths causes the longer wavelength emission and is thus indicative of an energy transfer type of process. Although the final emission is apparently from the tag, to further explore the mechanism time-resolved fluorescence measurements were performed in order to elucidate if any other fluorescing species were present. In the case of this kind of photocleaveable compounds it can be expected that, as well as any locally excited state, there is the possibility of the formation of an ion pair that can either recombine or cleave. A study was performed using an excitation wavelength of $349 \mathrm{~nm}$, which (considering the photolysis data) is the longest which can produce photocleavage in all of the compounds and opens this area to the use of twophoton excitation.
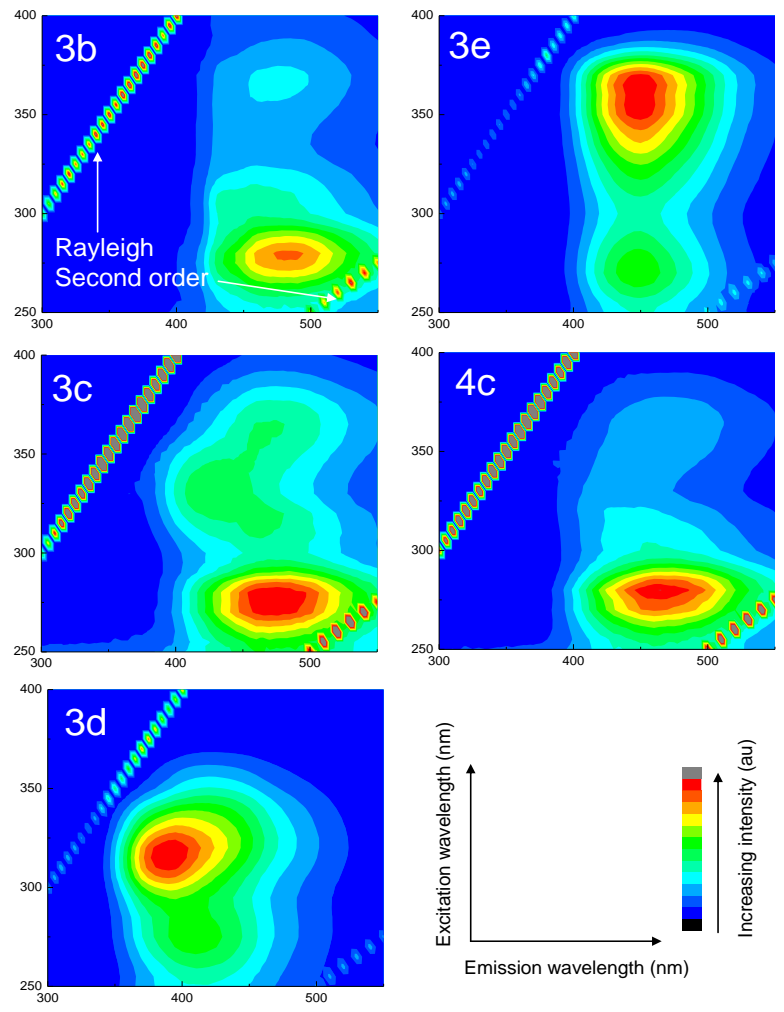

Figure 1. Excitation - emission matrices for selected compounds. The influence of scattered excitation light (first and second order) is also indicated. 
Time-resolved emission spectra were recorded (fluorescence decays measured for the same time at different wavelengths $-5 \mathrm{~nm}$ increments) and analysed globally to obtain decay associated spectra. Overall, these data (Figure 2) show the need to fit to a threeexponential decay model (indicative of three excited states) and these uncorrected spectra are obtained from the pre-exponential factor weighted by the lifetime.

The fact that the shortest lifetime is also at the shortest wavelength, with an increase in both lifetime and wavelength for the component spectra, can indicate a common origin. It can also be noted that the removal of the $N$-tert-butoxycarbonyl (Boc) group (3c to $4 c$ ) did not have any significant effect.
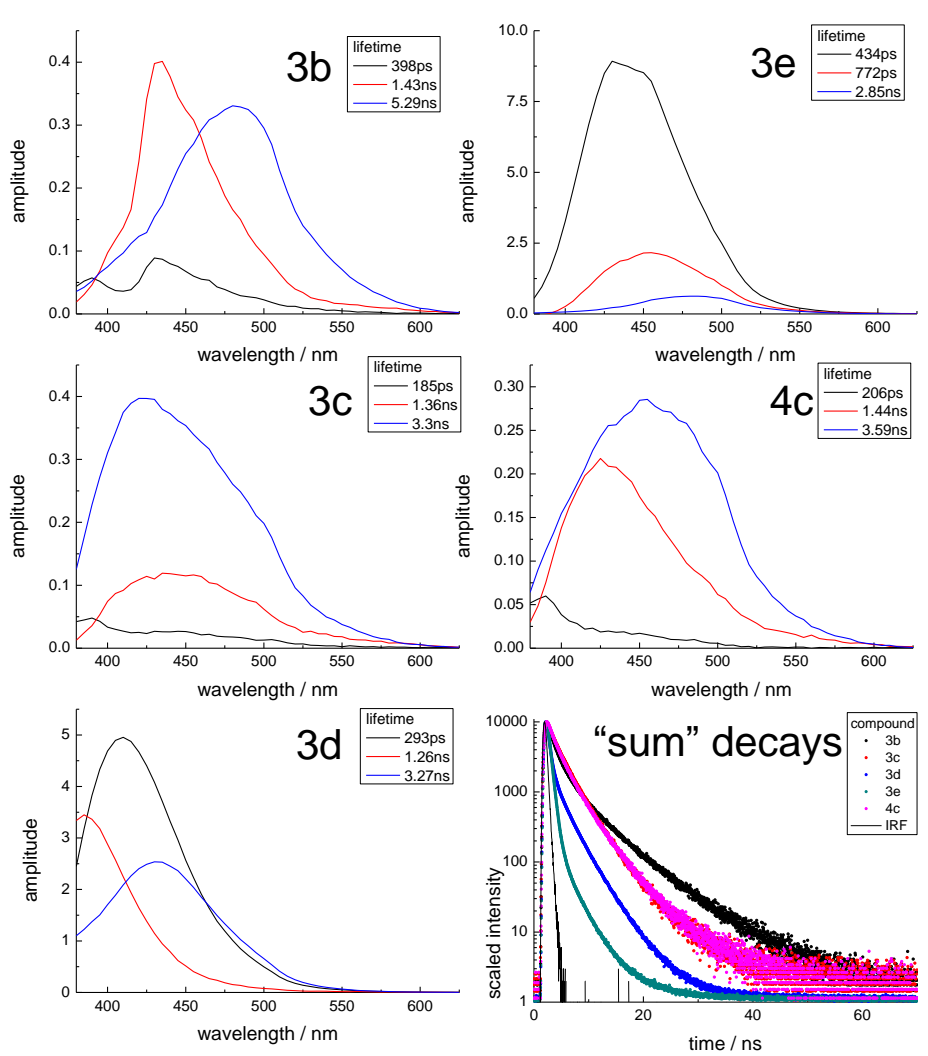

Figure 2. Decay associated spectra obtained from a 3-exponential global analysis for selected compounds. The (scaled) sum decays made by the addition of all the decays in the time-resolved emission measurements ( 380 to $625 \mathrm{~nm}$ at $5 \mathrm{~nm}$ increments) are also shown.

Photolysis studies of 5-aminolevulinic acid conjugates 3a-e and 4c

Conjugates 3a-e and 4c were irradiated at 254, 300, 350 and $419 \mathrm{~nm}$ in mixtures of methanol with aqueous HEPES buffer in 80:20 ratio, in a Rayonet RPR-100 reactor, and kinetic data were collected. The course of the photolytic reaction was followed by reverse phase HPLC with UV detection. The plots of peak area $(A)$ of the starting material 
versus irradiation time were obtained for each compound, at the considered wavelengths. Peak areas were determined by HPLC, which revealed a gradual decrease with time, and were the average of three runs. The irradiation time given represents the time necessary for the consumption of the starting materials until less than $5 \%$ of the initial area was detected (Table 2). For each compound, and based on HPLC data, the plot of In A versus irradiation time showed a linear correlation for the disappearance of the starting material. This is indicative of a first order reaction, obtained by the linear least squares methodology for a straight line. The photochemical quantum yields ( $\left.\Phi_{\text {phot }}\right)$ were calculated based on half-lives $\left(t_{1 / 2}\right)$, molar extinction coefficients $(\varepsilon)$ and the incident photon flux $\left(\mathrm{I}_{0}\right)$, which was determined by potassium ferrioxalate actinometry. ${ }^{41}$

The results in Table 2 for the various wavelengths of irradiation revealed the significant influence of the photoactive unit structure in the irradiation time $\left(t_{\text {irr }}\right)$ necessary to release 5-aminolevulinic acid. Although a study at the shorter wavelengths of irradiation ( 254 and $300 \mathrm{~nm}$ ) was carried out for comprehensiveness and the results are included in Table 2, the main focus of this work was the performance at 350 and $419 \mathrm{~nm}$, as these wavelengths are more adequate for biological applications. At these wavelengths, it was found that the release occurred from the different cages with shorter $t_{\text {irr }}$ for the irradiation at $350 \mathrm{~nm}$, with the exception of cage $\mathbf{3 b}$ which displayed similar irradiation time. Altogether, the best result at $350 \mathrm{~nm}$ was obtained with compound $\mathbf{3 e}$, bearing the fused oxazole coumarin with a chromone substituent, with $95 \%$ of the caged 5aminolevulinic acid being released in just $10 \mathrm{~min}$.

Table 2. Irradiation times ( $t_{\text {irr }}$, in $\mathrm{min}$ ) and photochemical quantum yields ( $\Phi_{\text {Phot }} \times 10^{-3}$ ) for the photolysis of conjugates $3 a-e$ and $\mathbf{4 c}$ at different wavelengths in methanol/HEPES buffer (80:20) solution.

\begin{tabular}{|c|c|c|c|c|c|c|c|c|}
\hline \multirow{2}{*}{ Cpd. } & \multicolumn{2}{|c|}{$254 \mathrm{~nm}$} & \multicolumn{2}{|c|}{$300 \mathrm{~nm}$} & \multicolumn{2}{|c|}{$350 \mathrm{~nm}$} & \multicolumn{2}{|c|}{$419 \mathrm{~nm}$} \\
\hline & $t_{i r r}$ & $\Phi_{\text {Phot }}$ & $t_{i r r}$ & $\Phi_{\text {Phot }}$ & $t_{\text {irr }}$ & $\Phi_{\text {Phot }}$ & $t_{i r r}$ & $\Phi_{\text {Phot }}$ \\
\hline $3 a$ & 89 & 0.0024 & 145 & $<0.001$ & 87 & $<0.001$ & 280 & $<0.001$ \\
\hline $3 b$ & 25 & 0.94 & 38 & 0.33 & 47 & 0.19 & 43 & 0.25 \\
\hline $3 c$ & 38 & 0.50 & 111 & 0.085 & 162 & 0.060 & 232 & 0.039 \\
\hline $3 d$ & 31 & 0.070 & 45 & 0.13 & 51 & 0.12 & $>1200$ & a) \\
\hline $3 e$ & 21 & 0.082 & 18 & 0.41 & 10 & 0.086 & 798 & 0.010 \\
\hline $4 c$ & a) & a) & a) & a) & 360 & 0.037 & a) & a) \\
\hline
\end{tabular}

a) not determined.

To establish whether optical control over the bond scission could be exercised, an experiment was attempted making use of fluorescence to monitor the kinetics of this process. Cleavage of the conjugate should remove a non-radiative pathway, thus 
increasing the quantum yield of the fluorophore. However, to exert control and check for an "on - off" behaviour is not trivial as it involves modulating the light source, and in the "off" condition this would also remove the source of the fluorescence excitation. In an initial attempt to overcome this, an approach was made using two excitation sources; one better tuned, in terms of wavelength, to the photocleavage process and another longer wavelength source to monitor the fluorescence. Compound $3 e$ was chosen as model, as the irradiation time for the cleavage process at shorter wavelengths was considerably shorter than that at longer wavelengths (see Table 2). To this end, an excitation source at $295 \mathrm{~nm}$ was used to modulate the photocleavage process and one at $392 \mathrm{~nm}$ was employed to monitor the fluorescence. Although in principle both wavelengths can contribute to both the fluorescence and the bond scission, as the data in Table 2 shows, the influence on photocleavage of the longer wavelength source should be significantly smaller. The contribution of the shorter wavelength source to the fluorescence intensity can also be taken into account as a background level and corrected. The set up made use of the time-resolved fluorimeter with an extra excitation channel added to the sample chamber opposite to the standard one.

An experiment was conducted, firstly with the $295 \mathrm{~nm}$ source in continuous irradiation, and then repeated with this source first turned on, then off and finally on again. The outcome is shown in Figure 3 and shows an initial similar trend in the increase in fluorescence intensity between the two runs, but when the shorter wavelength source is turned off there is a "plateau" with no significant increase until it is turned on again. This is indicative of the fact that light modulates the photocleavage process and that this approach is worthy of further study to obtain kinetic information.

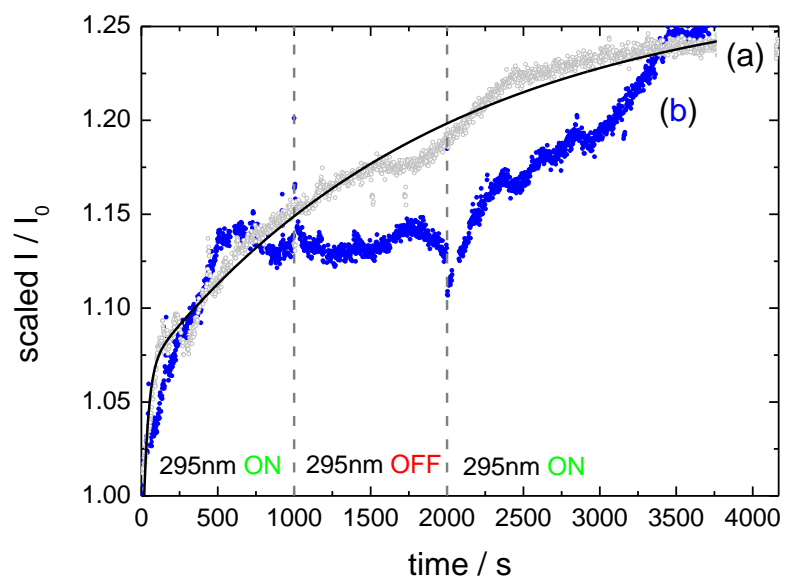

Figure 3. Change in fluorescence intensity (monitored at $465 \mathrm{~nm}$ ) for (a) continuous irradiation at $295 \mathrm{~nm}$ and (b) modulated irradiation $295 \mathrm{~nm}$. Fluorescence was "probed" at $392 \mathrm{~nm}$ and traces have been corrected for both excitation source contributions. 
Regarding the structure of the heterocyclic photosensitive moiety, comparison of the behaviour methoxybenzocoumarin $\mathbf{3 a}$ with aminobenzocoumarin $\mathbf{3 b}$, bearing the substituents at the same ring position (position 6), showed that the amino substituent improved the photosensitivity in the release of the active molecule as the $t_{\text {irr }}$ were consistently shorter with compound $\mathbf{3} \mathbf{b}$ at all the wavelengths of irradiation tested. The amino substituent at position 6 was crucial for the photolytic behaviour since the amino group at position 7 (compound $3 \mathbf{c}$ ) lead to a significant increase in the irradiation times when compared to $\mathbf{3 b}$, at all wavelengths tested.

Comparison of the data for oxazole fused coumarins $\mathbf{3} \mathbf{d}$ and $\mathbf{3 e}$, bearing a simple phenyl or a chromone ring linked to the oxazole, respectively, it was found that the extra heterocycle in $3 e$ had a beneficial effect in the photolytic reaction, which occurred faster for all the wavelengths of irradiation. It should be noted that in the decay associated spectra (Figure 2) these compounds exhibit dominant spectra associated with a short lifetime, when excited at $349 \mathrm{~nm}$. Longer irradiation times were required for compounds 3c and 4c which exhibited dominant longer-lived spectra. As already mentioned, photolysis at $350 \mathrm{~nm}$ and longer wavelengths is preferable for biological applications, and the data obtained by irradiation at $419 \mathrm{~nm}$ revealed a promising result for aminobenzocoumarin-caged 5-ALA 3b, with a practical irradiation time of $43 \mathrm{~min}$. Photolysis of the deprotected aminolevulinic acid conjugate $4 \mathrm{c}$ was also carried out by irradiation at $350 \mathrm{~nm}$ and revealed a dramatic difference in the irradiation time necessary for the release of the active molecule in its free form $\mathbf{5}$. This behaviour can be related to the higher propensity of the free amino group in the conjugate form to engage in hydrogen bonding to the solvent which in turn can lead to an increase in the rate constants of excited state deactivation through processes other than bond scission.

In addition to monitoring the photolysis process by HPLC, the release of 5-(N-BOC)aminolevulinic acid 2 was also followed by ${ }^{1} \mathrm{H}$ NMR in methanol- $\mathrm{d}_{4} / \mathrm{D}_{2} \mathrm{O}(80: 20)$ solution. As a representative example, in the photolysis of conjugate $\mathbf{3 b}$ at $300 \mathrm{~nm}$ the signal of the benzylic-type $\mathrm{CH}_{2}$ at position 4 of the benzocoumarin, visible at about $\delta 5.4 \mathrm{ppm}$, gradually decreased with time. The same observation occurred with the signals related to Boc-5-ALA in the conjugated form, at about $\delta 3.95,2.90$ and $2.80 \mathrm{ppm}$, giving rise to a close set of signals corresponding to Boc-5-ALA in its free form at about $\delta 3.90,2.75$ and $2.60 \mathrm{ppm}$, respectively (Figure 4). NMR monitoring was carried out with a $4.3 \times 10^{-4}$ $M$ solution, which led to an expected increase in the photolysis time for the complete release of the molecule, when compared to the irradiation times in Table 2 obtained with dilute solutions and can be related to the relatively higher optical density. 


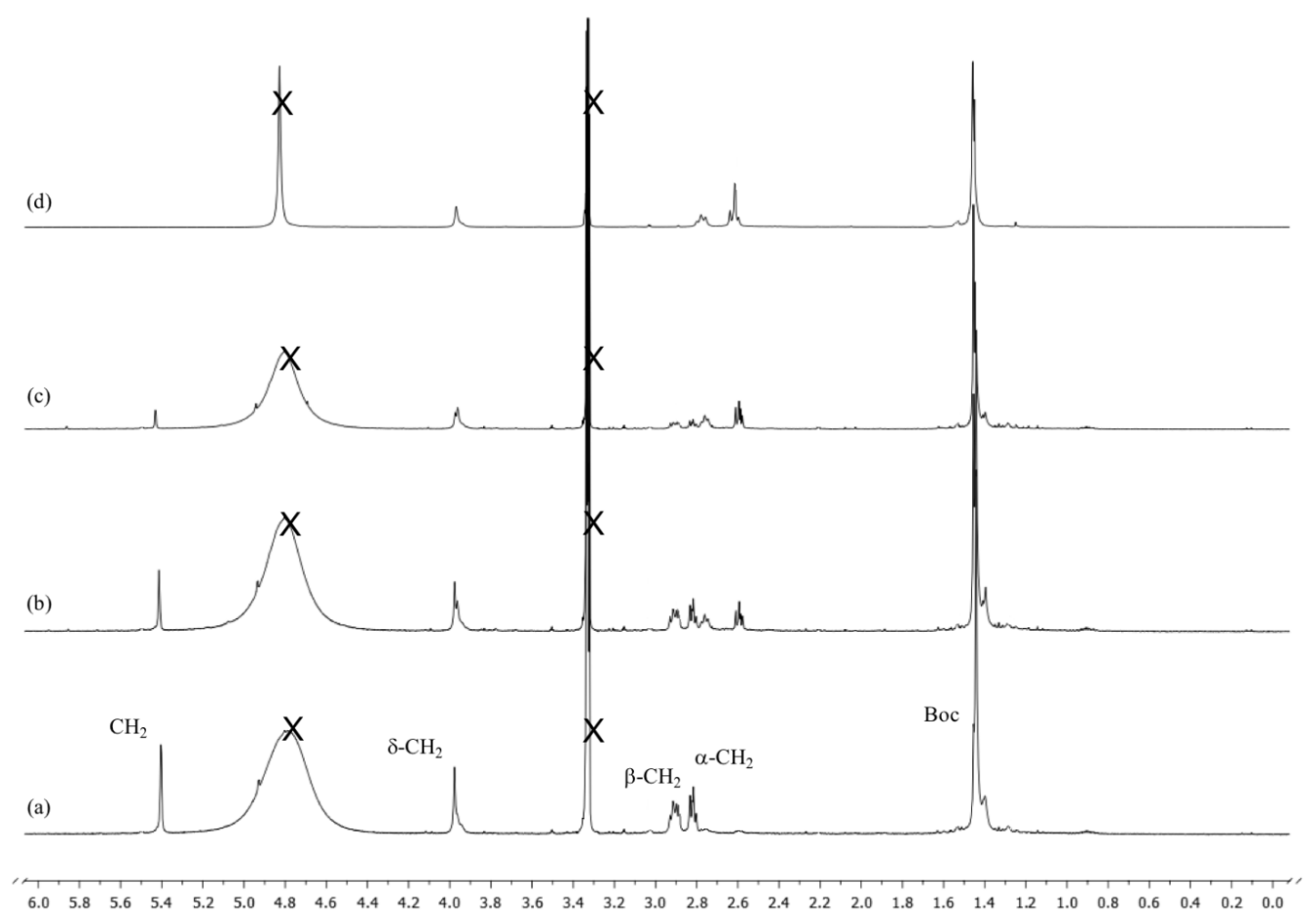

Figure 4. ${ }^{1} \mathrm{H}$ NMR spectra in methanol- $d_{4} / \mathrm{D}_{2} \mathrm{O}(80: 20)$ of the photolysis of conjugate $3 \mathbf{b}$ $\left(\mathrm{C}=4.3 \times 10^{-4} \mathrm{M}\right.$ ) at $300 \mathrm{~nm}$ : (a) before irradiation; (b) after irradiation for $45 \mathrm{~min}$; (c) after irradiation for $135 \mathrm{~min}$; (d) sample of free Boc-5-ALA 2.

To obtain further proof of release of the target molecule, through a mechanism previously suggested by us and others, ${ }^{38,42}$ involving ionic intermediates, MS spectra were obtained for the mixture resulting from the photolysis of conjugate $3 e$ in $\mathrm{MeOH} / \mathrm{HEPES}(80: 20)$ buffer after irradiation at $350 \mathrm{~nm}$ for $60 \mathrm{~min}$ (C = 3.7 $\left.\times 10^{-4} \mathrm{M}\right)$. In the obtained spectrum, the most relevant peaks were assigned to the released Boc-5-ALA 2 as base peak with $m / z=254$ (includes sodium), in accordance with the result obtained by ${ }^{1} \mathrm{H}$ NMR monitoring, and to a coumarinyl alcohol byproduct resulting from nucleophilic attack of water to the intermediate carbocation with $m / z=384$ (includes sodium). Coumarinyl esters are thought to photocleave through both homolytical or heterolytical fission of the $\mathrm{O}-\mathrm{CH}_{2}$ bond (the latter being energetically favourable). The homolysis of the $\mathrm{O}-\mathrm{C}$ bond, followed by electron transfer, can yield the ion pair (a methylenic coumarinyl carbocation and the leaving group anion), whereas heterolysis of the same bond directly affords the cited ion pair. Once formed, the coumarinyl carbocation can undergo nucleophilic attack by the solvent to form the final products (Scheme 3). 


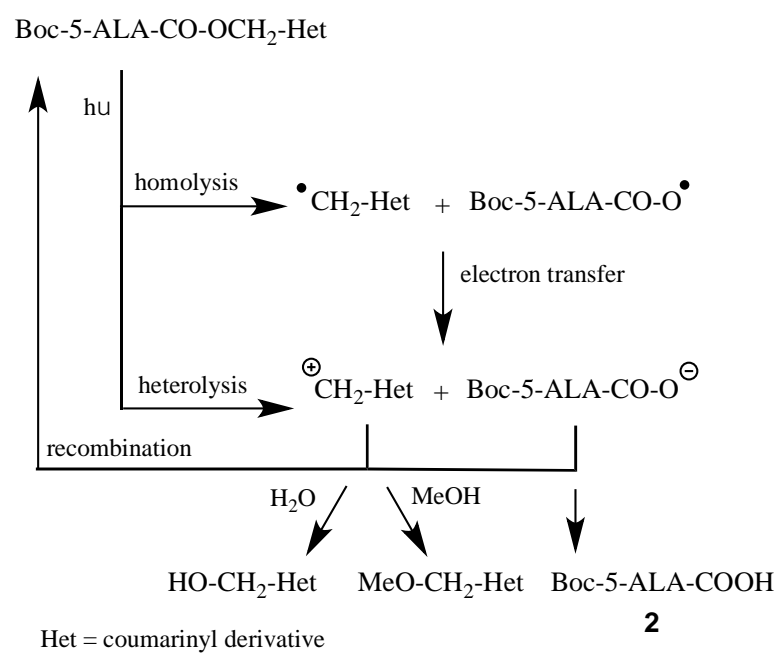

Scheme 3. Proposed mechanism for the photolysis of 5-ALA coumarinyl ester conjugates.

\section{Conclusions}

A series of heterocyclic cages, consisting of more extended conjugated systems based on coumarin, were used in the preparation of ester cages of 5-(N-Boc)-aminolevulinic acid and studied for the controlled delivery of the active molecule by photolysis at selected wavelengths (254, 300, 350 and $419 \mathrm{~nm}$ ), monitored by HPLC-UV and ${ }^{1} \mathrm{H}$ NMR. Overall, the results obtained confirmed the suitability of the tested photosensitive moieties for the release of 5-aminolevulinic acid at the various wavelengths of irradiation. The time-resolved fluorescence elucidated the presence of different fluorescing species in the compounds indicative of a multistep cleavage process. The use of two excitation sources (cleave and probe) to enable fluorescence to follow the kinetics of the process and to ascertain optical control over the bond scission appears promising. For benzocoumarins 3a-c the attachment position of the methoxy and amino substituents influenced the behaviour towards light of the corresponding cages, and the shortest irradiation times were obtained for the 6-aminobenzocoumarin $\mathbf{3 b}$, with emphasis on the result at $419 \mathrm{~nm}$. As for the oxazole fused coumarins, the best results in the photorelease of aminolevulinic acid were obtained for the chromone-bearing derivative $3 e$, especially at $350 \mathrm{~nm}$.

\section{Experimental}

\section{Materials}

All melting points were measured on a Stuart SMP3 melting point apparatus. TLC analyses were carried out on $0.25 \mathrm{~mm}$ thick precoated silica plates (Merck 
Fertigplatten Kieselgel $60 \mathrm{~F}_{254}$ ) and spots were visualised under UV light. Chromatography on silica gel was carried out on Merck Kieselgel (230-240 mesh). IR spectra were determined on a BOMEM MB 104 spectrophotometer in $\mathrm{KBr}$ discs (1\%). Absorption spectra $(200-700 \mathrm{~nm})$ were obtained using a Shimadzu UV/2501PC spectrophotometer. NMR spectra were obtained on a Bruker Avance III 400 at an operating frequency of $400 \mathrm{MHz}$ for ${ }^{1} \mathrm{H}$ and $100.6 \mathrm{MHz}$ for ${ }^{13} \mathrm{C}$ using the solvent peak as internal reference at $25^{\circ} \mathrm{C}$. All chemical shifts are given in ppm using $\delta_{\mathrm{H}} \mathrm{Me}_{4} \mathrm{Si}=0 \mathrm{ppm}$ as reference and $J$ values are given in $\mathrm{Hz}$. Assignments were supported by bidimensional heteronuclear correlation techniques. Mass spectrometry of the photolysis mixtures were obtained in a Finnigan LXQ mass spectrometer by ESI in positive ionization mode. High-resolution MS spectra were performed at the "C.A.C.T.I. - Unidad de Espectrometria de Masas", at University of Vigo, Spain. Fluorescence spectra were collected either using a FluoroMax-4 spectrofluorometer (HORIBA Scientific) or a FluoroLog 3 for the EEMs. Timeresolved fluorescence measurements were performed using a HORIBA Scientific DeltaFlex equipped with a DeltaDiode DD-350 excitation source.

All reagents were used as received. Chloromethyl precursors $1 \mathbf{a}^{29} \mathbf{1} \mathbf{b},{ }^{36} \mathbf{1} \mathbf{c}^{37} \mathbf{1 d}, \mathrm{e}^{38}$ and 5-(N-tert-butoxycarbonyl)aminolevulinic acid $\mathbf{2}^{17}$ were synthesised as reported elsewhere.

\section{General procedure for the synthesis of ester conjugates 3a-e.}

To a solution of the chloromethyl precursor 1a-e (1 equiv) in dry DMF, potassium fluoride (3 equiv), and 5-( $N$-tert-butoxycarbonyl)aminolevulinic acid (Boc-5-ALA) 2 (1 equiv) were added. The mixture was stirred at room temperature for $24 \mathrm{~h}$. The solvent was evaporated and the crude residue was purified by silica gel column chromatography using using ethyl acetate: $n$-hexane 4:6 as eluent (except for $\mathbf{4 c}$ which was pure after evaporation). The fractions containing the desired product were combined and evaporated.

(6-Methoxy-2-oxo-2H-benzo[h]benzopyran-4-yl)methyl

5-((tertbutoxycarbonyl)amino)-4-oxopentanoate, 3a. Starting from chloromethyl precursor 1a (0.024 g, $0.08 \mathrm{mmol})$, dry DMF ( $3 \mathrm{~mL})$, potassium fluoride $(0.023 \mathrm{~g}, 0.26 \mathrm{mmol}$ ) and Boc5-ALA 2 (0.019 g, $0.16 \mathrm{mmol})$, compound 3a was obtained as yellow solid (0.008 g, 0.01 $\mathrm{mmol}, 20 \%$ ). $\mathrm{mp}=189.2-190.2$ ㅇ․ TLC (ethyl acetate $/ n$-hexane 4:6): $R_{f}=0.67 . \mathrm{v}_{\max } / \mathrm{cm}^{-}$ 1 3315, 2925, 1735, 1714, 1687, 1600, 1538, 1475, 1455, 1422, 1386, 1355, 1291, 1198, $1165,1110,1087,1068,989,942,863,750,720,555 . \delta_{\mathrm{H}}\left(400 \mathrm{MHz}, \mathrm{CDCl}_{3}\right) 1.46(\mathrm{~s}, 9 \mathrm{H}$, $\left.\mathrm{C}\left(\mathrm{CH}_{3}\right)_{3}\right), 2.83\left(\mathrm{br} \mathrm{s}, 4 \mathrm{H}, \alpha-\mathrm{CH}_{2}\right.$ and $\left.\beta-\mathrm{CH}_{2}\right), 4.02(\mathrm{~s}, 3 \mathrm{H}, \mathrm{OCH})_{3}, 4.09\left(\mathrm{~d}, J 4.8 \mathrm{~Hz}, 2 \mathrm{H}, \delta-\mathrm{CH}_{2}\right)$, 5.20 (br s, 1H, NH), 5.38 (d, J $1.2 \mathrm{~Hz}, 2 \mathrm{H}, \mathrm{OCH}_{2}$ ), $6.58(\mathrm{~s}, 1 \mathrm{H}, \mathrm{H}-3), 6.63$ (s, 1H, H-5), 7.66$7.71(\mathrm{~m}, 2 \mathrm{H}, \mathrm{H}-8$ and $\mathrm{H}-9), 8.28(\mathrm{dd}, J 8.0$ and $1.2 \mathrm{~Hz}, 1 \mathrm{H}, \mathrm{H}-7), 8.53(\mathrm{dd}, J 8.0$ and $1.2 \mathrm{~Hz}$, $1 \mathrm{H}, \mathrm{H}-10) . \delta_{\mathrm{C}}\left(100.6 \mathrm{MHz}, \mathrm{CDCl}_{3}\right) 27.61\left(\alpha-\mathrm{CH}_{2}\right), 28.30\left(\mathrm{C}\left(\mathrm{CH}_{3}\right)_{3}\right), 34.25\left(\beta-\mathrm{CH}_{2}\right), 50.23(\delta-$ $\left.\mathrm{CH}_{2}\right), 55.94\left(\mathrm{OCH}_{3}\right), 62.38\left(\mathrm{OCH}_{2}\right), 80.01\left(\mathrm{C}\left(\mathrm{CH}_{3}\right)_{3}\right), 95.19$ (C-5), 112.02 (C-4a), 112.98 (C- 
3), 122.28 (C-7), 122.44 (C-10), 124.00 (C-10a), 127.35 (C-6a), 127.83 (C-9), 128.59 (C-8), 145.80 (C-10b), 148.82 (C-4), 152.35 (C-6), 155.38 (C=O Boc), 160.55 (C-2, C=O), 171.47 ( $\mathrm{C}=\mathrm{O}$ ester), 204.33 ( $\mathrm{C}=\mathrm{O}$ keto). (ESI) HRMS for $\mathrm{C}_{25} \mathrm{H}_{28} \mathrm{NO}_{8}\left[\mathrm{M}^{+}+\mathrm{H}\right]$ : calculated 470.18154 , found 470.18201 .

(6-Amino-2-oxo-2H-benzo[h]benzopyran-4-yl)methyl

5-((tertbutoxycarbonyl)amino)-4-oxopentanoate, $\mathbf{3 b}$. Starting from chloromethyl precursor $\mathbf{1 b}$ $(0.060 \mathrm{~g}, 0.23 \mathrm{mmol})$, dry DMF ( $3 \mathrm{~mL})$, potassium fluoride $(0.061 \mathrm{~g}, 0.69 \mathrm{mmol})$ and Boc5-ALA 2 (0.050 g, $0.23 \mathrm{mmol})$, compound 3b was obtained as a brown oil $(0.043 \mathrm{~g}, 0.09$ mmol, 42\%). TLC (ethyl acetate/ $n$-hexane 4:6): $R_{f}=0.64 . \mathrm{V}_{\max } / \mathrm{cm}^{-1} 3377,2960,2930$, $1699,1569,1510,1472,1433,1394,1253,1163,1086,958,859,766,733 . \delta_{H}(400 \mathrm{MHz}$, $\left.\mathrm{CDCl}_{3}\right) 1.44\left(\mathrm{~s}, 9 \mathrm{H}, \mathrm{C}\left(\mathrm{CH}_{3}\right)_{3}\right), 2.78-2.82\left(\mathrm{~m}, 4 \mathrm{H}, \alpha-\mathrm{CH}_{2}\right.$ and $\left.\beta-\mathrm{CH}_{2}\right), 4.07(\mathrm{~d}, J 4.8 \mathrm{~Hz}, 2 \mathrm{H}, \delta$ $\mathrm{CH}_{2}$ ), $5.23\left(\mathrm{~d}, J 0.8 \mathrm{~Hz}, 2 \mathrm{H}, \mathrm{OCH}_{2}\right), 5.32(\mathrm{br} \mathrm{s}, 1 \mathrm{H}, \mathrm{NH}), 6.47(\mathrm{~s}, 1 \mathrm{H}, \mathrm{H}-3), 6.60(\mathrm{~s}, 1 \mathrm{H}, \mathrm{H}-5)$, 7.61-7.64 (m, 2H, H-8 and H-9), $7.83(\mathrm{dd}, J 8.4$ and $1.6 \mathrm{~Hz}, 1 \mathrm{H}, \mathrm{H}-10), 8.46$ (dd, J 8.0 and $1.6 \mathrm{~Hz}, 1 \mathrm{H}, \mathrm{H}-7) . \delta_{\mathrm{C}}\left(100.6 \mathrm{MHz}, \mathrm{CDCl}_{3}\right) 27.56\left(\alpha-\mathrm{CH}_{2}\right), 28.28\left(\mathrm{C}\left(\mathrm{CH}_{3}\right)_{3}\right), 34.20\left(\beta-\mathrm{CH}_{2}\right)$,

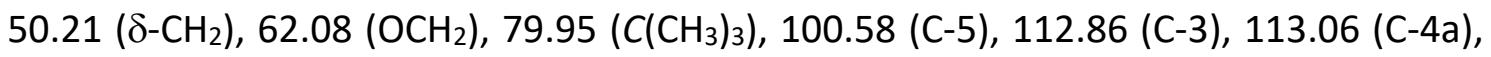
121.09 (C-7), 123.08 (C-10), 123.63 (C-6a), 125.59 (C-10a), 127.24 (C-9), 128.03 (C-8), 139.15 (C-6), 144.52 (C-10b), 149.07 (C-4), 155.68 (C=O Boc), 160.77 (C-2, C=O), 171.73 ( $\mathrm{C}=\mathrm{O}$ ester), 204.46 ( $\mathrm{C}=\mathrm{O}$ keto). (ESI) HRMS for $\mathrm{C}_{24} \mathrm{H}_{27} \mathrm{~N}_{2} \mathrm{O}_{7}\left[\mathrm{M}^{+}+\mathrm{H}\right]$ : calculated 455.18128 , found 455.18191 .

(7-Amino-2-oxo-2H-benzo[ $h]$ benzopyran-4-yl)methyl

5-((tertbutoxycarbonyl)amino)-4-oxopentanoate, 3c. Starting from chloromethyl precursor 1c (0.042 g, $0.16 \mathrm{mmol})$, dry DMF ( $3 \mathrm{~mL})$, potassium fluoride $(0.043 \mathrm{~g}, 0.49 \mathrm{mmol}$ ) and Boc5-ALA 2 (0.035 g, $0.16 \mathrm{mmol})$, compound 3c was obtained as a brown oil $(0.034 \mathrm{~g}, 0.08$ $\mathrm{mmol}, 55 \%$ ). TLC (ethyl acetate/n-hexane 4:6): $R_{f}=0.63 . \mathrm{v}_{\max } / \mathrm{cm}^{-1} 3447,3377,2980$, 2934, 1699, 1639, 1565, 1510, 1478, 1441, 1387, 1368, 1332, 1252, 1164, 1101, 1056, $981,855,789,750,735,700,679 . \delta_{\mathrm{H}}\left(400 \mathrm{MHz}, \mathrm{CDCl}_{3}\right) 1.45\left(\mathrm{~s}, 9 \mathrm{H}, \mathrm{C}\left(\mathrm{CH}_{3}\right)_{3}\right), 2.80-2.83$ $\left(\mathrm{m}, 4 \mathrm{H}, \alpha-\mathrm{CH}_{2}\right.$ and $\left.\beta-\mathrm{CH}_{2}\right), 4.09$ (d, J $\left.4.8 \mathrm{~Hz}, 2 \mathrm{H}, \delta-\mathrm{CH}_{2}\right), 5.24(\mathrm{br} \mathrm{s}, 1 \mathrm{H}, \mathrm{NH}), 5.34$ (d, J 1.2 $\left.\mathrm{Hz}, 2 \mathrm{H}, \mathrm{OCH}_{2}\right), 6.52(\mathrm{~s}, 1 \mathrm{H}, \mathrm{H}-3), 6.94(\mathrm{dd}, J 8.4$ and $0.8 \mathrm{~Hz}, 1 \mathrm{H}, \mathrm{H}-8), 7.34(\mathrm{~d}, J 8.8 \mathrm{~Hz}, 1 \mathrm{H}$, $\mathrm{H}-5), 7.43(\mathrm{t}, J 8.0 \mathrm{~Hz}, 1 \mathrm{H}, \mathrm{H}-9), 7.64(\mathrm{~d}, J 8.8 \mathrm{~Hz}, 1 \mathrm{H}, \mathrm{H}-6), 7.96(\mathrm{~d}, J 8.4 \mathrm{~Hz}, 1 \mathrm{H}, \mathrm{H}-10) . \delta_{\mathrm{c}}$

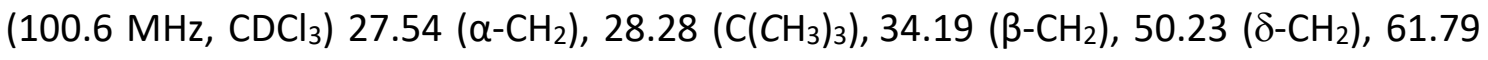
$\left(\mathrm{OCH}_{2}\right), 79.99\left(\mathrm{C}\left(\mathrm{CH}_{3}\right)_{3}\right), 112.18$ (C-4a), 112.33 (C-3), 121.88 (C-8), 113.07 (C-10), 117.39 (C-5), 117.67 (C-6), 124.07 (C-6a), 124.29 (C-10a), 127.98 (C-9), 142.30 (C-7), 149.53 (C4), 151.08 (C-10b), 155.67 ( $C=0$ Boc), 160.53 ( $C-2, C=0$ ), 171.72 ( $C=0$ ester), 204.15 ( $C=0$ keto). (ESI) HRMS for $\mathrm{C}_{24} \mathrm{H}_{27} \mathrm{~N}_{2} \mathrm{O}_{7}\left[\mathrm{M}^{+}+\mathrm{H}\right]$ : calculated 455.18128, found 455.18040 .

(6-Oxo-2-phenyl-6H-benzopyrano[6,7-d]oxazol-8-yl)methyl 5-((tert-butoxycarbonyl) amino)-4-oxopentanoate, 3d. Starting from chloromethyl precursor 1d (0.020 g, 0.064 $\mathrm{mmol})$, dry DMF (3 $\mathrm{mL})$, potassium fluoride $(0.017 \mathrm{~g}, 0.19 \mathrm{mmol}$ ) and Boc-5-ALA 2 (0.014 $\mathrm{g}, 0.064 \mathrm{mmol})$, compound $3 \mathrm{~d}$ was obtained as a beige solid $(0.020 \mathrm{~g}, 0.04 \mathrm{mmol}, 62 \%)$. 
$\mathrm{mp}=205.3-206.3$ ㅇ․ TLC (ethyl acetate $/ n$-hexane 4:6): $R_{f}=0.55 . \mathrm{v}_{\max } / \mathrm{cm}^{-1} 3415,2956$, 2925, 2855, 1718, 1634, 1559, 1490, 1441, 1441, 1398, 1370, 1329, 1291, 1260, 1160, $1141,1094,1049,1021,989,946,918,875,844,813,777 . \delta_{\mathrm{H}}\left(400 \mathrm{MHz}, \mathrm{CDCl}_{3}\right) 1.45$ (s, $\left.9 \mathrm{H}, \mathrm{C}\left(\mathrm{CH}_{3}\right)_{3}\right), 2.80-2.83\left(\mathrm{~m}, 4 \mathrm{H}, \alpha-\mathrm{CH}_{2}\right.$ and $\left.\beta-\mathrm{CH}_{2}\right), 4.07\left(\mathrm{~d}, J 5.2 \mathrm{~Hz}, 2 \mathrm{H}, \delta-\mathrm{CH}_{2}\right), 5.36(\mathrm{br} \mathrm{s}$, $1 \mathrm{H}, \mathrm{NH}), 5.37\left(\mathrm{~d}, J 1.6 \mathrm{~Hz}, 2 \mathrm{H}, \mathrm{OCH}_{2}\right), 6.52(\mathrm{t}, J 1.2 \mathrm{~Hz}, 1 \mathrm{H}, \mathrm{H}-7), 7.54-7.61(\mathrm{~m}, 4 \mathrm{H}, \mathrm{H}-4$ and $\mathrm{H}-3^{\prime}, \mathrm{H}-4^{\prime}$ and $\mathrm{H}-5^{\prime}$ ), 7.86 (s, $1 \mathrm{H}, \mathrm{H}-9$ ), 8.26 (dd, J 8.0 and $2.0 \mathrm{~Hz}, 2 \mathrm{H}, \mathrm{H}-2^{\prime}$ and $\left.\mathrm{H}-6^{\prime}\right) . \delta_{\mathrm{c}}$

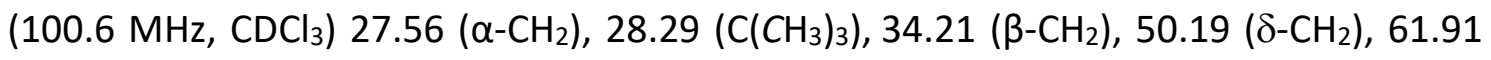
$\left(\mathrm{OCH}_{2}\right), 79.93\left(\mathrm{C}\left(\mathrm{CH}_{3}\right)_{3}\right), 99.84$ (C-4), 112.76 (C-7), 113.97 (C-9), 114.80 (C-8a), 126.12 (C$\left.1^{\prime}\right), 127.81$ (C-2' and C-6'), 129.05 (C-3' and C-5'), 132.34 (C-4'), 139.28 (C-9a), 148.95 (C8), 151.96 (C-4a), 152.50 (C-3a), 155.69 (C=O Boc), 160.13 (C-6, C=O), 164.98 (C-2), 171.63 ( $C=\mathrm{O}$ ester), 204.09 ( $\mathrm{C}=\mathrm{O}$ keto). (ESI) HRMS for $\mathrm{C}_{27} \mathrm{H}_{27} \mathrm{~N}_{2} \mathrm{O}_{8}\left[\mathrm{M}^{+}+\mathrm{H}\right]$ : calculated 507.17619, found 507.17617.

(6-Oxo-2-(4'-oxo-4H-benzopyran-2'-yl)-6H-benzopyrano[6,7-d]oxazol-8-yl)methyl 5((tert-butoxycarbonyl)amino)-4-oxopentanoate, 3e. Starting from chloromethyl precursor 1e $(0.041 \mathrm{~g}, 0.11 \mathrm{mmol})$, dry DMF $(3 \mathrm{~mL})$, potassium fluoride $(0.028 \mathrm{~g}, 0.11$ $\mathrm{mmol}$ ) and Boc-5-ALA 2 (0.023 g, $0.11 \mathrm{mmol})$, compound 3e was obtained as a beige solid (0.034 g, $0.06 \mathrm{mmol}, 56 \%) . \mathrm{mp}=235.4-235.3$ ㅇ․ TLC (ethyl acetate/ $n$-hexane 4:6): $R_{f}=0.60 . v_{\max } / \mathrm{cm}^{-1} 3427,3084,2926,2854,1733,1653,1573,1509,1464,1440,1387$, $1366,1328,1249,1159,1127,1052,956,899,860,778,755,735 . \delta_{\mathrm{H}}\left(400 \mathrm{MHz}, \mathrm{CDCl}_{3}\right)$ $1.45\left(\mathrm{~s}, 9 \mathrm{H}, \mathrm{C}\left(\mathrm{CH}_{3}\right)_{3}\right), 2.80-2.84\left(\mathrm{~m}, 4 \mathrm{H}, \alpha-\mathrm{CH}_{2}\right.$ and $\left.\beta-\mathrm{CH}_{2}\right), 4.09\left(\mathrm{~s}, 2 \mathrm{H}, \delta-\mathrm{CH}_{2}\right), 5.26(\mathrm{br} \mathrm{s}$, $1 \mathrm{H}, \mathrm{NH}), 5.40$ (d, J $\left.1.2 \mathrm{~Hz}, 2 \mathrm{H}, \mathrm{OCH}_{2}\right), 6.59$ (s, 1H, H-7), $7.36\left(\mathrm{~s}, 1 \mathrm{H}, \mathrm{H}-3^{\prime}\right), 7.52(\mathrm{dt}, J 7.2$ and $\left.1.2 \mathrm{~Hz}, 1 \mathrm{H}, \mathrm{H}-6^{\prime}\right), 7.70(\mathrm{~s}, 1 \mathrm{H}, \mathrm{H}-4), 7.71\left(\mathrm{dd}, J 8.0\right.$ and $\left.1.2 \mathrm{~Hz}, 1 \mathrm{H}, \mathrm{H}-8^{\prime}\right), 7.81(\mathrm{dt}, J$ 8.0 and $\left.1.6 \mathrm{~Hz}, 1 \mathrm{H}, \mathrm{H}-7^{\prime}\right), 8.07(\mathrm{~s}, 1 \mathrm{H}, \mathrm{H}-9), 8.27$ (dd, J 8.0 and $\left.1.2 \mathrm{~Hz}, 1 \mathrm{H}, \mathrm{H}-5^{\prime}\right) . \delta_{\mathrm{C}}(100.6$ $\left.\mathrm{MHz}, \mathrm{CDCl}_{3}\right) 27.45\left(\alpha-\mathrm{CH}_{2}\right), 28.30\left(\mathrm{C}\left(\mathrm{CH}_{3}\right)_{3}\right), 34.22\left(\beta-\mathrm{CH}_{2}\right), 50.18\left(\delta-\mathrm{CH}_{2}\right), 61.72\left(\mathrm{OCH}_{2}\right)$, $79.99\left(\mathrm{C}\left(\mathrm{CH}_{3}\right)_{3}\right), 100.51$ (C-4), 113.24 (C-3'), 113.73 (C-7), 115.91 (C-9), 116.02 (C-8a), 118.55 (C-8'), 124.56 (C-4a'), 125.99 (C-6'), 126.19 (C-5'), 134.87 (C-7'), 138.29 (C-8), 148.57 (C-9a), 150.42 (C-2'), 152.35 (C-4a), 152.46 (C-3a), 153.20 (C-8a'), 156.13 (C=0 Boc), 157.54 (C-2), 159.46 (C-6, C=O), 171.67 ( $C=0$ ester), 177.29 (C-4'), 203.98 ( $C=0$ keto). (ESI) HRMS for $\mathrm{C}_{30} \mathrm{H}_{27} \mathrm{~N}_{2} \mathrm{O}_{10}\left[\mathrm{M}^{+}+\mathrm{H}\right]$ : calculated 575.16602, found 575.16419.

Synthesis of (7-amino-2-oxo-2H-benzo[h]benzopyran-4-yl)methyl 5-amino-4oxopentanoate, 4c. Conjugate 3c $(0.020 \mathrm{~g}, 0.05 \mathrm{mmol})$ was dissolved in dichloromethane/TFA $(2: 1)(3 \mathrm{~mL})$ and the reaction mixture was stirred at room temperature for $1 \mathrm{~h}$. The solvent was evaporated giving the expected deprotected compound 4c as a brown oil $(0.011 \mathrm{~g}, 0.03 \mathrm{mmol}, 68 \%)$. TLC (ethyl acetate/ $n$-hexane 8:2): $R_{f}=0.23 . v_{\max } / \mathrm{cm}^{-1} 3437,3375,2982,2937,2124,1700,1635,1505,1476,1439$, $1388,1370,1330,1249,1165,1099,1045,983,850,786,749,738,705,680 . \delta_{H}(400$ $\left.\mathrm{MHz}, \mathrm{DMSO}-d_{6}\right) 2.78\left(\mathrm{t}, J 6.4 \mathrm{~Hz}, 2 \mathrm{H}, \alpha-\mathrm{CH}_{2}\right), 2.89\left(\mathrm{t}, J 6.4 \mathrm{~Hz}, 2 \mathrm{H}, \beta-\mathrm{CH}_{2}\right), 3.98(\mathrm{br} \mathrm{s}, 2 \mathrm{H}$, $\left.\delta-\mathrm{CH}_{2}\right), 5.49\left(\mathrm{~d}, J 1.2 \mathrm{~Hz}, 2 \mathrm{H}, \mathrm{OCH}_{2}\right), 6.52(\mathrm{~d}, J 1.6 \mathrm{~Hz}, 1 \mathrm{H}, \mathrm{H}-3), 6.88(\mathrm{dd}, J 7.6$ and $0.8 \mathrm{~Hz}$, $1 \mathrm{H}, \mathrm{H}-8$ ), 7.40 (t, J $8.0 \mathrm{~Hz}, 1 \mathrm{H}, \mathrm{H}-9$ ), 7.54 (d, J $8.8 \mathrm{~Hz}, 1 \mathrm{H}, \mathrm{H}-5), 7.56$ (dd, J 8.0 and $1.2 \mathrm{~Hz}$, 
$1 \mathrm{H}, \mathrm{H}-10), 8.00(\mathrm{~d}, J 8.8 \mathrm{~Hz}, 1 \mathrm{H}, \mathrm{H}-6) . \delta_{\mathrm{c}}\left(100.6 \mathrm{MHz}, \mathrm{DMSO}-d_{6}\right) 27.03\left(\alpha-\mathrm{CH}_{2}\right), 34.25(\beta-$ $\left.\mathrm{CH}_{2}\right), 46.75\left(\delta-\mathrm{CH}_{2}\right), 61.67\left(\mathrm{OCH}_{2}\right), 108.66(\mathrm{C}-10), 110.68$ (C-8), 111.13 (C-3), 112.11 (C4a), 117.41 (C-5), 119.13 (C-6), 123.27 (C-6a), 123.52 (C-10a), 128.52 (C-9), 145.26 (C-7), 150.19 (C-10b), 151.29 (C-4), 159.85 (C-2, C=O), 171.80 ( $C=0$ ester), 202.84 ( $C=0$ keto). (ESI) HRMS for $\mathrm{C}_{19} \mathrm{H}_{19} \mathrm{~N}_{2} \mathrm{O}_{5}\left[\mathrm{M}^{+}+\mathrm{H}\right]$ : calculated 355.12885, found 355.12875.

\section{Photolysis general procedure:}

A $1 \times 10^{-4} \mathrm{M}$ methanol/HEPES (80:20) solution of compounds 3a-e and $\mathbf{4 c}(5 \mathrm{~mL})$ were placed in a quartz tube and irradiated in a Rayonet RPR-100 reactor at the desired wavelength. The lamps used for irradiation were of 254, 300, 350 and $419 \pm 10 \mathrm{~nm}$. HEPES buffer solution was prepared in distilled water with HEPES (4-(2-hydroxyethyl)-1piperazine ethanesulfonic acid) $(10 \mathrm{mM})$, sodium chloride $(120 \mathrm{mM})$, potassium chloride ( $3 \mathrm{mM})$, calcium chloride $(1 \mathrm{mM})$ and magnesium chloride $(1 \mathrm{mM})$ and $\mathrm{pH}$ adjusted to 7.2 with aqueous $1 \mathrm{M}$ sodium hydroxide solution. Aliquots of $100 \mu \mathrm{L}$ were taken at regular intervals and analysed by RP-HPLC using a Licrospher $100 \mathrm{RP} 18(5 \mu \mathrm{m})$ column in a JASCO HPLC system composed by a PU-2080 pump and a UV-2070 detector with ChromNav software. The eluent was acetonitrile/water, 75:25 at a flow rate of 0.8 $\mathrm{mL} / \mathrm{min}$, previously filtered through a Millipore, type $\mathrm{HN} 0.45 \mu \mathrm{m}$ filter and degassed by ultra-sound for $30 \mathrm{~min}$. The chromatograms were traced by detecting UV absorption at the wavelength of maximum absorption for each compound (retention time: $\mathbf{3 a}, 6.2 ; \mathbf{3 b}$, $4.3 ; 3 c, 4.4 ; 3 d, 6.5 ; 3 e, 7.1 ; 4 c, 4.0 \mathrm{~min}$ ). The fluorescence kinetic measurements involved the use of a DeltaFlex with an additional excitation channel. A DeltaDiode DD295 was operated at $100 \mathrm{MHz}$ to provide the "cleavage" source and a DD-395L was used as a "probe". A KV370 filter was used on the emission to block any $295 \mathrm{~nm}$ light and the EzTime software was operated in "histogram streaming" mode, with histograms collected every two seconds. The intensity was taken from the total number of counts in each histogram.

\section{Acknowledgements}

Thanks are due to the Fundação para a Ciência e Tecnologia (FCT, Portugal) for financial support to the NMR portuguese network (PTNMR, Bruker Avance III 400-Univ. Minho), FCT and FEDER (European Fund for Regional Development)-COMPETE-QREN-EU for funds provided through the Chemistry Research Centre of the University of Minho (Ref. UID/QUI/00686/2013 and UID/QUI/0686/2016). A PhD grant to A.M.S.S. (SFRH/BD/80813/2011) is also acknowledged. 


\section{References}

1 B. Krammer, K. Plaetzer. Photochem. Photobiol. Sci., 2008, 7, 283-289.

2 N. Fotinos, M. A. Campo, F. Popowycz. Photochem. Photobiol., 2006, 82, 9941015.

3 K. A. Frei, H. M. Bonel, H. Frick. Br. J. Cancer, 2004, 90, 805-809.

4 Q. Peng, K. Berg, J. Moan, M. Kongshaug, J. M. Nesland. Photochem. Photobiol., 1997, 65, 235-251.

5 P. K. Nootheti, M. P. Goldman. Dermatol. Clin., 2007, 25, 35-45.

6 S. Q. Tao, F. Li, L. Cao, R. S. Xia, H. Fan, Y. Fan, H. Sun, C. Jing, L. J. Yang. Cell Biochem. Biophys., 2015, 73, 701-706.

7 E. W. Jeffes, J. L. McCullough, G. D. Weinstein, P. E. Fergin, J. S. Nelson, T. F. Shull, K. R. Simpson, L. M. Bukaty, W. L. Hoffman, N. L. Fong. Arch. Dermatol., 1997, 133, 727- 732.

8 T. Hasegawa, Y. Suga, Y. Mizuno, K. Haruna, H. Ogawa, S. Ikeda. J. Dermatol., 2010, 37, 623-628.

9 T. Dai, Y. Y. Huang, M. R. Hamblin. Photodiagn. Photodyn. Ther., 2009, 6, 170188.

10 O. E. Akilov, S. Kosaka, K. O’Riordan, T. Hasan. Photochem. Photobiol. Sci., 2007, 6, 1067-1075.

11 T. Zhou, L. Shao, S. Battah, C. Zhu, R. Hider, B. Reeder, A. Jabeen, S. MacRobert, G. Ren, X. Liang. Med. Chem. Commun., 2016, 7, 1190-1196.

12 A. Stenzl, H. Penkoff, E. Dajc-Sommerer, A. Zumbraegel, L. Hoeltl, M. Scholz, C. Riedl, J. Bugelnig, A. Hobisch, M. Burger, G. Mikuz, U. Pichlmeier. Cancer, 2011, 117, 938-947.

13 R. F. V. Lopez, N. Lange, R. Guy, M. V. L. B. Bentley. Adv. Drug Deliv. Rev., 2004, 56, 77-94.

14 J. M. Gaullier, K. Berg, Q. Peng, H. Anholt, P. K. Selbo, L. W. Ma, J. Moan. Cancer Res., 1997, 57, 1481-1486.

15 J. H. Yoon, H. E. Yoon, O. Kim, S. K. Kim, S. G. Ahn, K. W. Kang. Lasers Surg. Med., 2012, 44, 76-86.

16 C. J. Whitaker, S. H. Battah, M. J. Forsyth, C. Edwards, R. W. Boyle, E. K. Matthews. Anti-Cancer Drug Des., 2000, 15, 161-170.

17 G. Berkovitch, D. Doron, A. Nudelman, Z. Malik, A. Rephaeli. J. Med. Chem., 2008, 51, 7356-7369.

18 G. Di Venosa, L. Hermida, A. Batlle, H. Fukuda, M. V. Defain, L. Mamone, L. Rodriguez, A. MacRobert, A. Casas. J. Photochem. Photobiol. B Biol., 2008, 92, 1-9.

19 F. Giuntini, L. Bourre, A. J. MacRobert, M. Wilson, I. M. Eggleston. J. Med. Chem., 2009, 52, 4026-4037. 
20 G. Di Venosa, P. Vallecorsa, F. Giuntini, L. Mamone, A. Batlle, S. Vanzuli, A. Juarranz, A. J. MacRobert, I. M. Eggleston, A. Casas. Mol. Cancer Ther., 2015, 14, 440-451.

21 M. Wachowska, A. Muchowicz, M. Firczuk, M. Gabrysiak, M. Winiarska, M. Wańczyk, K. Bojarczuk, J. Golab. Molecules, 2011, 16, 4140-4164.

22 A. Kasche, S. Luderschmidt, J. Ring, R. Hein. J. Drugs Dermatol., 2006, 5, 353356.

23 Y. Hotta, T. Tanaka, H. Takaoka, Y. Takeuchi, M. Konnai. Plant Growth Regul., 1997, 22, 109-114.

24 C. A. Rebeiz, K. N. Reddy, U. B. Nandihalli, J. Velu. Photochem. Photobiol., 1990, 52, 1099-1117.

25 Ch. Sasikala, Ch. V. Ramana, P. Raghuveer Rao. Biotechnol. Prog., 1994, 10, 451-459.

26 L. Bildstein, C. Dubernet, P. Couvreur. Adv. Drug Deliv. Rev., 2011, 63, 3-23.

27 F. Kratz, I. A. Müller, C. Ryppa, A. Warnecke. ChemMedChem, 2008, 3, 20-53.

28 S. E. Jin, H. E. Jin, S. S. Hong. Biomed. Res. Int., 2014, 814208.

29 A. M. S. Soares, S. P. G. Costa, M. S. T. Gonçalves. Amino Acids, 2010, 39, 121133.

30 A. M. S. Soares, S. P. G. Costa, M. S. T. Gonçalves. Tetrahedron, 2010, 66, 81898195.

31 G. Hungerford, L. Ryderfors, M. J. G. Fernandes, M. S. T. Gonçalves, S. P. G. Costa. J. Photochem. Photobiol. A: Chem., 2010, 215, 214-222.

32 A. S. C. Fonseca, M. S. T. Gonçalves, S. P. G. Costa. Amino Acids, 2010, 39, 699712.

33 A. M. S. Soares, A. M. Piloto, G. Hungerford, S. P. G. Costa, M. S. T. Gonçalves. Eur. J. Org. Chem., 2012, 922-930.

34 A. M. Piloto, G. Hungerford, S. P. G. Costa, M. S. T. Gonçalves. Eur. J. Org. Chem., 2013, 34, 7715-7723.

35 A. M. Piloto, G. Hungerford, J. U. Sutter, A. M. S. Soares, S. P. G. Costa, M. S. T. Gonçalves. J. Photochem. Photobiol. A, 2015, 299, 44-53.

36 A. M. S. Soares, G. Hungerford, S. P. G. Costa, M. S. T. Gonçalves. Eur. J. Org. Chem., 2015, 27, 5979-5986.

37 A. M. S. Soares, G. Hungerford, S. P. G. Costa, M. S. T. Gonçalves. New J. Chem., 2015, 39, 7227-7233.

38 A. M. S. Soares, G. Hungerford, S. P. G. Costa, M. S. T. Gonçalves. Dyes Pigments, 2017, 137, 91-100.

39 F. S. Tjoeng, G. A. Heavner. Synthesis, 1981, 897-899.

40 J. V. Morris, M. A. Mahaney, J. R. Huber. J. Phys. Chem., 1976, 80, 969-974.

41 C. Muller, P. Even, M.-L. Viriot, M.-C. Carré. Helv. Chim. Acta, 2001, 84, 37353741. 
42 P. Klán, T. Solomek, C. G. Bochet, A. Blanc, R. Givens, M. Rubina, V. Popik, A. Kostikov, J. Wirz. Chem. Rev., 2013, 113, 119-191. 